\title{
AdDRESSING GENDER QUOTAS IN SOUTH AFRICA: WOMEN EMPOWERMENT AND GENDER EQUALITY LEGISLATION
}

\section{JANINE HILLs*}

A significant development in the area of gender quota legislation is driven by South Africa's latest National Policy Framework for Women Empowerment and Gender Equality (WEGE) legislation. This legislation expands on the values and principles that need to be integrated into policies, practices and programs of the private sector and government to ensure gender equality and quotas. The legislation strives for 50 per cent female representation on the executive bodies of all organisations. Another unique feature of diversity in South Africa is achieved through the Black Economic Empowerment (BEE) Program. South Africa's BEE Scorecard Policies and Empowerment Strategies are unique, affecting quota decisions and behaviour.

\section{INTRODUCTION}

\section{A The Significance of Gender Quotas and International Developments}

Due to the growing impatience with the slow pace of voluntary change, gender quotas are coming more into focus in South Africa. Women are the majority of all graduates almost everywhere in the developed world, but make up a smaller share of the workforce the further up the corporate ladder they go. Around the globe 'the demand for greater gender equality in the boardroom is higher than ever before'. ${ }^{1}$

Governments and businesses all over the world continue to engage in discussions about the best approach to increasing women's representation on

\footnotetext{
* Founder and CEO, Vuma Reputation Management, Johannesburg, South Africa.

${ }^{1}$ Catalyst, Increasing Gender Diversity on Boards: Current Index of Formal Approaches (8 August 2014) <http://www.catalyst.org/knowledge/increasing-gender-diversity-boardscurrent-index-formal-approaches>.
} 
boards. Thus far, efforts have fallen into three distinct areas: legislative, regulatory and voluntary. Three quarters of US corporate board member respondents indicated that their company had taken steps to support and promote boardroom diversity efforts in the past three years. Four fifths ${ }^{2}$ agreed that diversity in the boardroom generally results in increased value for shareholders. $^{3}$

When Norway introduced a mandatory 40 per cent quota of female directors for listed companies in 2006, to be enforced in 2008, it was the first country to adopt legislation. 'Non-complying firms could theoretically be forcibly dissolved, though none has in fact suffered such a fate' yet. ${ }^{4}$

Since then, gender quotas for boards have been imposed by legislation — albeit in different ways and with different quota percentages - in Belgium, Iceland, Italy, the Netherlands and Spain, although with less severe sanctions than Norway's. Non-complying firms must generally only explain in their annual reports why they have fallen short and what they plan to do about it.

There have been some remarkable developments in Germany since 2013, eventually leading to legislation being adopted for the equal participation of men and women in management positions in private enterprises and public services. ${ }^{5}$ The European Commission is also considering imposing quotas across the EU. On 20 November 2013, the European Union (EU) Parliament voted by a large majority in favour of a Directive requiring member states to legislate to achieve at least 40 per cent participation by each gender on the boards of, inter alia, listed companies. 'The governments of several other

\footnotetext{
${ }^{2}$ Ibid.

${ }^{3}$ Spencer Stuart and Corporate Board Member, 2012 Boardroom Diversity Survey: Summary Report (17 July 2012) <http://content.spencerstuart.com/sswebsite/pdf/lib/2012-BoardroomDiversity-Survey-Summary-Report_17Jul2012.pdf $>$; Spencer Stuart, Corporate Boards Taking Steps To Promote Diversity (July 17 2012) Spencer Stuart Press Release $<$ https://www.spencerstuart.com/who-we-are/media-center/corporate-boards-taking-steps-topromote-diversity>. The survey was sent to 697 directors on the Corporate Board Member Research Panel and 1850 governance and nominating committee members and chairs of USbased publicly traded companies.

${ }^{4} \mathrm{H}$ J, The Spread of Gender Quotas for Company Boards (25 March 2014) The Economist $<$ http://www.economist.com/blogs/economist-explains/2014/03/economist-explains14\#sthash.Y4O1UPNh.dpuf>.

${ }^{5}$ See Raphael Koch, 'Board Gender Quotas in Germany and the EU: An Appropriate Way of Equalization of Women and Men?' (2015) 20(1) Deakin Law Review 53, 60, referring to the Act of 24 April 2015 BGBl. I 642.
} 
countries, including Australia, Britain and Sweden, have threatened to impose quotas if firms do not appoint more female directors voluntarily.' ${ }^{6}$

South Africa performs relatively well in the global movement towards closing the gender gap. The Women Empowerment and Gender Equality Bill (the WEGE Bill) ${ }^{7}$ has passed the National Assembly, though some serious concerns with it have been raised. Therefore, the legislation has been referred back to Parliament for further consultation, but the message is clear, namely, that it is highly likely that gender quotas will become law in South Africa in the foreseeable future. The legislation, if it becomes law, would probably be the most radical mandatory gender quota legislation in the world, forcing all organisations, corporations, and government departments to have 50 per cent women on their decision-making bodies.

Through mapping voluntary, constitutional and legislated quotas across southern Africa, the 2013 SADC Gender Protocol ${ }^{8}$ Barometer shows that in both local government and parliament, countries with quotas have a far higher representation of women (37 per cent and 38 per cent respectively) than those without (16 per cent and 9 per cent respectively). ${ }^{9}$

Regardless of whether a specific country mandates a quota for women on boards or not, it is clear that the global trends and movements in recruitment foreshadow a sprint for top talent to fill board vacancies. Given the even distribution of talent across the genders, companies that are not addressing the gender diversity of their boards run the risk of being left behind. ${ }^{10}$

\section{B This Is Why Gender Diversity Matters}

Boards of directors 'make decisions about executive compensation, whether to buy, sell, or merge with other companies, where corporate offices close or

\footnotetext{
${ }^{6} \mathrm{H}$ J, above $\mathrm{n} 4$.

7 Women Empowerment and Gender Equality Bill 2012 (South Africa) <https:// jutalaw.co.za/media/filestore/2013/11/B50_2013.pdf>.

${ }^{8}$ Southern African Development Community, SADC Protocol on Gender and Development $<$ http://www.genderlinks.org.za/attachment.php?aa_id=2392>.

${ }^{9}$ Colleen Lowe Morna et al (eds), SADC Gender Protocol 2013 Barometer (Published Gender Links, 2013).

10 Joann S Lublin, “'Pink Quotas” Alter Europe’s Boards: Gender Mandates, Expertise in Hot Fields Bring Foreign Directorships to More American Women' The Wall Street Journal (online), 11 September 2012 <http://online.wsj.com/articles/SB1000087239639044 3696604577645470530827882>.
} 
relocate, and how much priority a company gives to issues other than profits, such as social responsibility'. ${ }^{11}$

Good corporate decision-making thus requires the ability to hear and consider different points of view which come from people who have different backgrounds, cultures, experiences, and perspectives. Companies that have women directors and executives lead by example. They send a clear message that they value diversity of thought and experience. While the advantages and disadvantages of each approach are open to debate, the general consensus is that appointing more women to positions of leadership and boards is smart business, is good for business, and is a proactive image and reputation builder. Whether or not to appoint women to board level is a business issue, and not a women's issue. ${ }^{12}$

\section{SOUTH AFRICA's History OF WOMEN'S PARTICIPATION}

The country's first presidents in the democratic era, the late Nelson Mandela (1918-2013) and Thabo Mbeki, were two leaders who led the way in transformation and in empowering women to participate in a democratic economy. Improvements to the status of women in South Africa were very important to Nelson Mandela. He has been credited with opening the door to women's empowerment after South Africa's 1994 democratic elections. ${ }^{13}$ Freedom cannot be achieved unless women have been emancipated from all forms of oppression. Women should be empowered to participate in all aspects of life as equals alongside all other members of society.

Formal acknowledgment of equality between the sexes followed, along with the recognition of women's rights. South Africa's new Constitution, passed in 1996, reflects this change clearly in an equality clause. ${ }^{14}$ This has been followed through in subsequent pieces of legislation, such as the Employment Equity Act

\footnotetext{
11 Why Gender Diversity Matters, 20/20: 20\% by 2020 Women on Boards <http://www.2020wob.com/learn/why-gender-diversity-matters>.

12 Interview with Malcolm Larsen (Vuma Reputation Management, Illovo, Sandton, South Africa, 8 October 2014). Malcolm Larsen is a co-founder of Business Engage, an organisation at the forefront of SME development and the empowerment of women.

13 See Nelson Mandela, State of the Nation Address by the President of South Africa, Nelson Mandela (24 May 1994) South African History Online <http://www.sahistory.org.za/article/ state-nation-address-president-south-africa-nelson-mandela>.

${ }^{14}$ Constitution of the Republic of South Africa Act 1996 (South Africa) ch 2, s 9, available at: <http://www.constitutionalcourt.org.za/site/theconstitution/thetext.htm>.
} 
of $1998,{ }^{15}$ which introduced affirmative action for designated groups. The proportion of women in South Africa's Parliament increased ten-fold from 2.7 per cent before the 1994 elections to 27 per cent immediately thereafter. This increased to 30 per cent in 1999, 33 per cent in 2004 and 44 per cent after the 2009 elections. In 2002 the ruling ANC party adopted a voluntary 30 per cent quota for women and, in 2007, the party raised it to 50 per cent at both national and local levels. ${ }^{16}$

In 2009 the ANC also adopted a policy that 50 per cent of all ANC candidates for national elections should be women. It is currently the only party that has a voluntary quota for women. Local government representation followed a similar trend, however in the 2011 local government elections women's representation declined from 40 per cent to 38 per cent, because of a decline in the ANC's majority.

Today, the figure for all women in Parliament stands at 44 per cent, while 42 per cent of cabinet members are women. This makes South Africa's legislature and cabinet among the top ten most representative in the world. However, after 20 years of democracy, only between 21 per cent and 23 per cent of economic decision-making positions are occupied by women, and women make up only four per cent of CEOs of private companies - far less than government quotas. Considering this country's history, South Africa has come exceptionally far in the last 20 years. But, given the persistent inequalities and social injustices, we have to admit that it has not been 20 years of democracy, but rather 20 years towards democracy. 'Although numbers do not guarantee the achievement of gender equality and do not ensure change, critical mass remains a pre-requisite for transformation'. ${ }^{17}$

\section{What's Holding Most South African Women BACK?}

The following is a list of the factors that are holding back the women of South Africa.

\footnotetext{
${ }^{15}$ Employment Equity Act 1998 (South Africa) < http://www.acts.co.za/employment-equity-act$1998 />$.

${ }^{16}$ Katherine Robinson, South Africa: Snubbing Quotas for Women, Snubs Transformation (7 February 2014) Gender Links for Equality and Justice <http://www.genderlinks.org.za/article/ south-africa-snubbing-quotas-for-women-snubs-transformation-2014-02-07> .

${ }^{17}$ Ibid.
} 


\section{- Lack of Education}

South Africa has made enormous progress in addressing the education of the previously marginalised population. The proportion of girls under 19 years of age attending school increased from 21 per cent to 66 per cent between 1995 and 1999. 'In the years from 2002-2006, 81\% of the population aged 15-19 was attending school and the majority of the students were women.' ${ }^{18}$ Despite the progress made, 'rural young women still face many challenges, including delayed and cut education due to long distances to get to school, poorly resourced school [sic], educators who sexually harass them, bullying and others [sic] ${ }^{19}$ as well as violence, domestic duties and pregnancies. ${ }^{20}$ 'Many girls drop out of school before they reach grade 12. Other girls drop-out to head households in cases when the children have been orphaned by HIV-AIDS.' ${ }^{21}$ 'Forced marriages of particularly young women and girls ... include the rape of the victim which often leads to enormous health problems compromising sexual and reproductive health.' 22

\section{- Harmful Domestic and Cultural Practices}

Although the South African Constitution guarantees the right of equality to all citizens, ${ }^{23}$ established cultural norms are often at odds with constitutional provisions. Still, the government and the judicial system have consistently upheld the rights of women against culture-based oppression, and entrenched the supremacy of the Constitution. In spite of this, women remain subjected to numerous harmful cultural traditional and religious practices across all sectors and in all tribal communities. ${ }^{24}$ This significantly impedes their access to rights.

\footnotetext{
${ }^{18}$ Masimanyane Women's Support Centre, South African NGO Shadow Report, Responding to the Combined $2^{\text {nd }}$, $3^{\text {rd }}$ and $4^{\text {th }}$ Periodic Report of the Government of South Africa and Providing Alternative Information on the SA Government's Implementation of the Convention on the Elimination of All Forms of Discrimination against Women (CEDAW) (17 January-4 February 2011) 15 <http://www2.ohchr.org/english/bodies/cedaw/docs/ngos/MasimanyaneWomens SupportCentre_for_the_session_SouthAfrica_CEDAW48.pdf $>$.

19 Thabisa Bobo, Challenges of Rural Women Masimanyane Women's Support Centre, 2 $<$ http://www.masimanyane.org.za/sites/default/files/Challenges\%20facing\%20rural\%20wome n.doc $>$.

${ }^{20}$ Masimanyane Women's Support Centre, above n 18, 15.

${ }^{21}$ Bobo, above n 19, 3.

${ }^{22}$ Masimanyane Women's Support Centre, above n 18, 26.

${ }^{23}$ Constitution of the Republic of South Africa, above $n 14$.

${ }^{24}$ Bobo, above n 19, 3. See generally UNICEF, Promoting Quality Education for Orphans and Vulnerable Children: A Sourcebook of Programme Experiences in Eastern and Southern Africa (November 2009) <http://www.unicef.org/spanish/education/files/Promoting_Quality_ Education_for_Orphans_and_Vulnerable_Children_Programmes_from_Eastern_and_Souther n_Africa.pdf $>$.
} 
Rural women are especially vulnerable as they are forced to submit to tribal authorities who do not favour women's rights. ${ }^{25}$

Access to land in rural communities is male dominated. Inheritance after the death of a spouse is taken up by male members of the family and women are often left destitute. Many women's groups report how they are requested to assist women who have lost their homes and possessions after the death of a partner. Some are thrown onto the streets without any further support. ${ }^{26}$ This practice increases poverty and women's vulnerability in general.

Culture, tradition and religion play a very significant role in guiding and influencing most aspects of women's lives, and increasing their vulnerability to poverty, violence and other forms of oppression and discrimination. Traditional beliefs in rural areas include the belief in ancestors, traditional healers and witchcraft. Witches/sorcerers are often blamed for illness and misfortune and, once identified, are frequently brutally murdered and burnt (and we all know that the majority of those are unfortunately women). ${ }^{27}$ South Africa has a unique culture and heritage, giving identity and recognition to traditional practices, ${ }^{28}$ but they should not be abused to advance personal interests. Chiefs and traditional leaders need to partner with government and support its efforts to anchor women and youth in the forefront of socio-economic transformation.

\section{- Unemployment Rates}

It was stated in the Report of the International Women's Forum South Africa in 2011 that:

An important obstacle to the achievement of gender equality in South Africa is the high level of unemployment which has been caused by historical factors such as economic stagnation during the time of apartheid, years of racial and

\footnotetext{
25 Bobo, above n 19, 3

26 Ibid.

27 Business Day Live, Princess Takes Claim to Xhosa Throne to Court (6 August 2012) <http://www.bdlive.co.za/articles/2011/07/26/princess-takes-claim-to-xhosa-throne-to-court; jsessionid=F2AFC1354166416AF0B0A0F55591DC3B.present2.bdfm $>$. The princess Noma Xhosa Sigcawu claimed her chieftaincy and felt discriminated against on the basis of gender, according to customary law, as only the eldest male heir could become a chief in the community.

28 See South African History Online, Defining Culture, Heritage and Identity (2015) $<$ http://www.sahistory.org.za/topic/defining-culture-heritage-and-identity>.
} 
gender discrimination as well as recent factors such as the global economic downturn in $2008 .^{29}$

Employment increased between 1997 and 2008, 'however this growth was not enough to benefit poor households, many of which have high dependency ratios with few earners supporting many family members'. ${ }^{30}$

The incidence of structural unemployment has particularly affected women, with two out of three women reported as being discouraged by their failure to secure employment. ${ }^{31}$

Moreover, the group pressure of peers and elders is sometimes found to brainwash youngsters into believing that there are no jobs to be had. Such beliefs are based on the deep-rooted inequalities in childcare and household work which still restrict opportunities for women, and impact on career possibilities and working patterns. Women's role in society is still highly restricted. Women are expected to undertake child care, to care for the sick, and to fetch water and fuel, rather than to be economically productive and employed, and to engage adequately with the broader economy.

\section{- The Disparity between Types of Employment for Men and Women}

While access to income-earning employment has improved, a wide disparity exists between types of employment for men and women, with women frequently employed in part-time work and informal economies. ${ }^{32}$ Additional factors influence women's choices of work and the opportunities available to them as opposed to those available to men. Occupational segregation remains rife, with women predominant in jobs of inferior status, and fewer women present in managerial, and other high status roles. ${ }^{33}$

\footnotetext{
${ }^{29}$ International Women's Forum South Africa, The Status of Women in South Africa (October 2011), 4 <http://www.iwfsa.co.za/index.php/programmes/norwegian-project/item/download /3_d3c47dc5de9c83abeac5ad81458c59c5>.

30 Ibid.

31 Ibid 13.

32 The International Trade Union Confederation and Income Data Services, The Global Gender Pay Gap (February 2008), 8 <http://www.ituc-csi.org/IMG/pdf/gap-1.pdf>.

33 Ibid 47.
} 


\section{- The Limited Pool of Women Who Possess the Required Skills}

There is currently a limited pool of women with the required skills and talents to operate in the corporate environment. 'Women that do fit this profile have a lot of the time followed a path of entrepreneurship and created their own empires and companies. ${ }^{34}$

They are thus not being captured by the opportunities created by, for example, major corporate bodies, such as JSE (Johannesburg Stock Exchange)-listed companies. This challenge 'could be addressed and overcome by ensuring the right tools and platforms are in place in order to identify and skill-up young women in line with industry needs'. ${ }^{35}$

\section{- No Access to Finance}

Gender remains an important variable and the lack of funding access has left South African women marginalised.

[A lack of] access to finance is one of the biggest deterrents prohibiting women establishing their own ventures. Women should be able to access funding at all levels, from ground level to the top. This can be achieved through offtake agreements and innovative finance mechanisms. ${ }^{36}$

\section{Why Women ARE INTEgRal ENTITIES IN CORPORATE AND GOVERNMENT LEADERSHIP}

Women should not just feature in the economy; they should shape it. ${ }^{37}$ The following is a list of the reasons why women are integral to corporate and government leadership.

\section{- Women on Boards Increase Profits}

There has been considerable debate about whether there is a 'business case' for having more women on boards, or, put in another way, whether there is a correlation between increasing the number of women on boards and increased

\footnotetext{
${ }^{34}$ International Women’s Forum South Africa, above n 29, 43, citing Dr Anna Mokgokong.

${ }^{35}$ Ibid.

${ }^{36}$ Ibid 44.

${ }^{37}$ Interview with Malcolm Larsen, above n 12.
} 
company profits. ${ }^{38}$ Research shows that companies with one or more women on the board have delivered higher average returns on equity, lower gearing and better average growth than companies with only men on the board. ${ }^{39}$ Research has found that net income growth for companies with women on the board has averaged 14 per cent over the past six years, compared to 10 per cent for those with no female board representation. ${ }^{40}$ However there are no clear indicators of why this is so. A number of explanations have been suggested. It could be because of the women's skills and ability to perform well, or it could be because the women's participation causes a rise in the reputation and image of the company, or because other women are more comfortable doing business with women.

\section{- Women Bring Diversity of Thought to the Boardroom}

Women on boards bring different perspectives to the difficult issues facing today's corporations, resulting in better decision-making and innovation. The more companies hire people of different genders and backgrounds the more competitive they will become. Diversity helps companies to overcome talent shortages by enlarging their talent pools. ${ }^{41}$

\section{- Women Tend to Have More Intuition Than Men}

Carmona states that: 'Women tend to be more intuitive than men in decisionmaking. Men are persuaded by graphs, charts, and hard numbers, while women are interested in all of these' plus more humane approaches. 'Women want to

\footnotetext{
${ }^{38}$ Credit Suisse Research Institute, Gender Diversity and Corporate Performance (August 2012), 6, 14-16. See also Katie Watson, 'Gender Diversity on Corporate Boards' (2014) 7(1) Journal of the Australasian Law Teachers Association 1, 3-4, <http://s3-ap-southeast-2.amazonaws. com/resources.farm1.mycms.me/alta-edu-au/Resources/PDFs/JALTA/2014/JALTA\%20 2014\%20Watson.pdf>; Jean du Plessis, James O’Sullivan and Ruth Rentschler, 'Multiple Layers of Gender Diversity on Corporate Boards: To Force or Not to Force?' (2014) 19(1) Deakin Law Review 1, 3-4; Jean du Plessis, Ingo Saenger and Richard Foster, 'Board Diversity or Gender Diversity: Perspectives from Europe, Australia and South Africa' (2012) 17(2) Deakin Law Review 207, 242-3 and the sources referred to in the footnotes. For further references to studies on the 'business case' for having more women on boards, see $<$ http://www.catalyst.org/knowledge/bottom-line-corporate-performance-and-womensrepresentation-boards-20042008>; <http://www.womenonboards.org.au/pubs/articles/1112why-women-are-good-for-business.htm>; <http://www.catalystwomenonboard.org/docs/thebusiness-case.pdf $>$.

${ }^{39}$ Credit Suisse Research Institute, above n 38.

${ }^{40}$ Ibid.

${ }^{41}$ Why Gender Diversity Matters, above n 11.
} 
understand the wider impact of their decision and prefer to have a more holistic picture' to spark intuition. '[T]hey are 'more at ease that they have made the right decision by considering all the multifaceted elements. ${ }^{42}$

\section{- Women Focus on Inclusion and Consultation}

According to Carmona:

The collaborative management style that women often display is sometimes misinterpreted as indecisive and can be seen as a weakness. However, looked at from a different perspective, this can be a major strength. ${ }^{43}$

She explains as follows: ${ }^{44}$

For example, the people that women leaders bring along with them on the decision-making journey tend to support them more once conclusions are reached. This fuels a hands-on, collaborative environment. [E]ven with an inclusive style, women are often more interested in getting the job done than in seeking personal praise.

\section{- Women Are More Humane, Nurturing and Empathetic}

It is the present author's experience that because most women are also mothers (and will eventually become grandmothers - the rock of the family), they are more caring, nurturing and empathetic than men, with a greater understanding of employees' situations, circumstances, challenges and what barriers they face in performing their duties.

\footnotetext{
${ }^{42}$ Cecily Carmona, SA's Female Economy: Women's Decisions Are Different-Survey (6 April 2014) BizNews.com <http://www.biznews.com/thought-leaders/2014/04/06/sas-femaleeconomy-women-getting-ahead-b2b/>; Cecily Carmona, Martin Sprott and Thando Mtshali, The Female Economy in B2B: A Lens on South Africa (March 2014) A T Kearney <http://www.atkearney.com/paper/-/asset_publisher/dVxv4Hz2h8bS/content/id/4371115>.

${ }^{43}$ Carmona, above $\mathrm{n} 42$.

${ }^{44}$ Ibid.
} 


\section{Factors PreVenting Women in Business from ADVANCING TO BOARD LEVEL}

A range of factors prevent women in business from advancing to board level. These are listed below.

\section{- Women Not Taking Ownership}

Women may not do enough themselves to succeed in the boardroom and to command respect. Women are also less likely than men to argue for higher salaries or bigger bonuses in performance reviews. Women therefore unintentionally hold themselves back in their careers. ${ }^{45}$

\section{- Internal Barriers}

Women are fearful of pushing aside obstacles and removing barriers. Women are not confident enough to break through these barriers and their past, limiting beliefs.

\section{- Diversity is More Complicated than Originally Thought}

Robust measures to increase women's share of senior management positions are a good thing but their success depends partly on whether management teams can be convinced that diversity is important. ${ }^{46}$ Diversity might improve performance by mirroring the diversity of customers, but on the other hand it might also increase conflict, worsen communication and reduce workplace trust.

Getting people from different cultural backgrounds to cooperate is fraught with difficulties and friction. The question is whether the creativity engendered by diversity is worth the conflict. Tension between people causes a hostile working environment and reduces people's ability to see non-obvious connections

\footnotetext{
45 Sheryl Sandberg, Lean In: Women, Work, and the Will to Lead (Deckle Edge, 2013). Sheryl Sandberg is Facebook's Chief Operating Officer. She is ranked on Fortune's list of the 50 Most Powerful Women in Business and as one of Time's 100 Most Influential People in the World.

${ }^{46}$ Schumpeter Business and Management, The Downside of Diversity (21 January 2014) The Economist <http://www.economist.com/blogs/schumpeter/2014/01/schumpeters-notebook>.
} 
between ideas from different cultures and this has a definite impact on women. ${ }^{47}$

\section{- Gender Bias in Hiring}

Research demonstrates that women are evaluated less positively than equally qualified men when applying for stereotypically male jobs, such as leadership roles. ${ }^{48}$ It has also been found that at times hiring criteria are adjusted specifically to disadvantage females seeking leadership positions. ${ }^{49}$ Hmurovic refers to several other examples of bias in hiring women for leadership positions. ${ }^{50}$

\section{- Occupational and Cultural Jealousy}

The Greek philosopher Antisthenes described the result of jealousy accurately when he stated: 'As iron is eaten by rust, so are the envious consumed by envy. ${ }^{51}$ Anyone who has not experienced jealousy at the office is either lying or in deep denial. People who 'envy others at work are associated with lower self-esteem and higher levels of Machiavellian behaviour' ${ }^{52}$ Women will kick the ladder down for other women, where men tend to assist women to the top. Cultural jealousy is also highly evident in South Africa where a person from the one culture will try to kick the other from another culture down, preventing them from getting to the top.

\footnotetext{
${ }^{47}$ Roy Chua, 'The Costs of Ambient Cultural Disharmony: Indirect Intercultural Conflicts in Social Environment Undermine Creativity’ (2013) 56(6) Academy of Management Journal 1545.

48 Jillian L Hmurovic, Faulted When Female? Gender-Biased Evaluative Judgments and Attributional Rationalalization in Response to Leader Failure (LLM Thesis, Michigan State University, 2012) 4 <http://etd.lib.msu.edu/islandora/object/etd\%3A619/datastream/OBJ/ view>.

${ }^{49}$ Ibid 30-1.

${ }^{50}$ Ibid 30-3 and 41-2.

${ }^{51}$ Sheila Norman-Culp, Workplace Jealousy: It Shoulda Been Mine! (26 October 2007) The Seattle Times <http://seattletimes.com/html/living/2003975075_jealousonthejob26.html>.

${ }^{52}$ Ibid. 'Robert Vecchio, a professor of management at Notre Dame, found that people who envy others at work were associated with lower self-esteem and higher levels of Machiavellian behavior': <http://business.nd.edu/newsandevents/mendoza_in_the_news_article.aspx?id $=1179>$.
} 


\section{- Inflexible Working Situations}

While companies could innovate and consider the provision of childcare facilities in the workplace, and/or introduce flexible working arrangements that enable women to balance career and domestic responsibilities, we have yet to see this taken up in earnest in South Africa.

\section{- Unequal Partners in Business Deals}

As stated in The Status of Women in South Africa report, women are 'not seen as equal partners in business deals, and are invited only at the last minute to paint the company in a favourable light'. ${ }^{53}$ '[F]emale board members should be more proactive and ensure that they involve themselves in ... business deals' from the start. ${ }^{54}$

\section{- Pay Parity - The Remuneration Inequality}

South Africa still has the elements of a patriarchal society. On average women still earn less than men. Statistics in 2013 revealed that South African women earned up to 33 per cent less than their male counterparts for the same work. ${ }^{55}$ The current international pay gap average is 13 per cent, and is still widening in certain countries. ${ }^{56}$

\section{- Companies Making It Difficult for Women to Break through Glass Ceilings}

Most companies are ignorant of national and regional treaties and commitments to gender equality. Employment equity plans are developed, but not implemented; sexual harassment policies are developed, but few cases are taken up. Generally, companies do not have a focused gender equality strategy with targets, proactive interventions and timeframes, nor do they implement women's empowerment and capacity-building programmes.

\footnotetext{
${ }^{53}$ International Women's Forum South Africa, above n 29, 44 citing Dr Anna Mokgokong, the Executive Chairperson of Community Investment Holdings.

54 Ibid.

55 World Economic Forum, The Global Gender Gap Report 2013 <http://www3.weforum. org/docs/WEF_GenderGap_Report_2013.pdf> 338.

${ }^{56}$ Ibid 8-11 (Table 3a).
} 


\title{
VI South Africa's National Policy Framework for WOMEN'S EMPOWERMENT AND GENDER EQUALITY
}

\begin{abstract}
A Background
South Africa's National Policy Framework for Women's Empowerment and Gender Equality was formulated by the Office on the Status of Women (OSW) and was adopted by Cabinet in December 2000. The Framework elaborates on values and principles which form the foundations of the National Gender Programme, and states that these principles need to be integrated into the policies, practices and programs of government to ensure the achievement of gender equality. ${ }^{57}$
\end{abstract}

Following the end of apartheid, in 1996 the Bill of Rights of the Constitution of the Republic of South Africa outlined the fundamental principle that the new democratic society had to respect and promote the rights of all its citizens indiscriminately, regardless of race, gender, class, age or disability ${ }^{58}$ In order to ensure that institutions pay attention to the mainstreaming of women in their policy-making, a 'National Gender Machinery’ was established. South Africa's National Gender Machinery was made up of several elements: the Office on the Status of Women (OSW), the Commission on Gender Equality (CGE), the Parliamentary Joint Monitoring Committee (JMC) on the Improvement of the Quality of Life and Status of Women and several gender-focused NGOs.

The National Policy Framework attempted to define the roles of these groups, and was adopted five years after the National Gender Machinery was set up. ${ }^{59}$ Preceding the publication of this framework, there was uncertainty as to the mandates of provincial and national offices of the OSW and the CGE. These organisations were also constrained by insufficient financial and human resources. The aim of the Gender Policy Framework is to take a significant step in striving for gender equality by enhancing the influence of the National Gender Machinery and by strengthening the voice of women in civil society,

57 Women Empowerment and Gender Equality Bill 2013 (South Africa) cl 3.2, available at <http://jutalaw.co.za/media/filestore/2013/11/B50_2013.pdf>.

${ }^{58}$ David Kgosimore, 'The Bill of Rights in the Constitution of the Republic of South Africa and its Application within the Criminal Justice System' (2000) 1(1) Crime Research in South Africa 1-10 <http://www.crisa.org.za/volume1/rights.htm>.

${ }^{59}$ See Office on the Status of Women, South Africa's National Policy Framework for Women's Empowerment and Gender Equality (2012) <http://www.gov.za/sites/www.gov.za/files/ gender_0.pdf> together with Nitasha Moothoo-Padayachie, Gender Mainstreaming in the South African Public Service (1 June 2011) Alternatives International Journal <http://www. alterinter.org/spip.php?article3555>. 
Parliament and in other organisations. The Framework is also intended to enhance the work carried out by bodies within the National Gender Machinery, and is aimed to add momentum to the implementation of South Africa's commitment to the agenda for women's empowerment - the Platform for Action - which was adopted after the World Conference on Women in Beijing in $1995 .{ }^{60}$ 'The framework stated that its success would be reflected in the ability of government to progress to gender equality in an "integrated and coordinated manner" and that the result should be a "fairer and transformed society' ${ }^{61}$

The ambitious objectives of the Framework are outlined at the outset of the document. These include: the translation of government commitment to gender equality into reality; the establishment of ways to empower women in all aspects of work, throughout government and within the broader society; and the institutionalisation of this Framework and promotion of a change in attitude to correspond with this new policy.

\section{B South Africa - Party to a Number of International Conventions and Agreements}

Currently, South Africa is signatory or party to a number of international conventions and agreements relating to gender equality and equity. These contain clear goals, indicators and measures to end discrimination against women in the workplace and to incorporate the principle of equality of men and women in legal systems. A few examples suffice:

- The United Nations Economic and Social Council's (ECOSOC) Commission on the Status of Women (CSW) principal global policy; ${ }^{62}$

\footnotetext{
${ }^{60}$ United Nations Entity for Gender Equality and the Empowerment of Women, Beijing and its Follow-up UN Women <http://www.un.org/womenwatch/daw/beijing/>.

${ }^{61}$ International Women's Forum South Africa, above n 29, 19-20.

62 UN Women, Commission on the Status of Women <http://www.unwomen.org/en/csw>. Dedicated exclusively to gender equality and advancement of women, the June 1946 mandate was expanded in 1987 to include the functions of promoting the objectives of equality, development and peace, monitoring the implementation of measures for the advancement of women, and reviewing and appraising progress made at the national, sub-regional, regional and global levels: <http://www.un.org/womenwatch/daw/cedaw/>.
} 
- The United Nations Convention on the Elimination of All Forms of Discrimination against Women (CEDAW) $-1979 ;^{63}$

- The Beijing Platform for Action — 1995; ${ }^{64}$

- The UN Millennium Development Goals — 2000; 65

- The Protocol to the African Charter on Human and Peoples' Rights on the Rights of Women in Africa — 2003; ${ }^{66}$

- The SADC (South African Development Community) Gender and Development Protocol — 2008. ${ }^{67}$

By virtue of these agreements, female board membership in South Africa has increased visibly in the government and private sectors.

These rights-based international and regional instruments feed into the mainstreaming strategy of South Africa's National Gender Machinery and its 'National Policy Framework on the empowerment of Women and Gender Equality', giving effect to these commitments. As a UN Member, South Africa is periodically required to report on its performance and compliance with all these agreements.

${ }^{63}$ United Nations Entity for Gender Equality and the Empowerment of Women, The United Nations Convention on the Elimination of All Forms of Discrimination against Women (CEDAW) UN Women <http://www.un.org/womenwatch/daw/cedaw/>.

${ }^{64}$ United Nations Entity for Gender Equality and the Empowerment of Women, Fourth World Conference on Women, Beijing Declaration and Platform for Action <http:// www.un.org/womenwatch/daw/beijing/platform/>.

${ }^{65}$ United Nations, We Can End Poverty: Millennium Development Goals and Beyond 2015 United Nations Millennium Development Goals <http://www.un.org/millenniumgoals/ bkgd.shtml>.

${ }^{66}$ African Commission and Human and Peoples' Rights, Protocol to the African Charter on Human and Peoples' Rights on the Rights of Women in Africa (11 July 2003) $<$ http://www.achpr.org/instruments/women-protocol/>.

${ }^{67}$ Southern African Development Community, Protocol on Gender and Development (17 August 2008) <http://www.sadc.int/documents-publications/show/803>. This sets targets for all regions for a 50 per cent representation of women in all areas of decision-making by 2020. 


\section{BROAD-BASED BLACK ECONOMIC EMPOWERMENT (B- BBEE) AND TRANSFORMATION}

The Broad-Based Black Economic Empowerment Act (the B-BBEE Act) was originally drafted in 1994 and, through various steps, finalised and adopted as a working framework in 2003. ${ }^{68}$ Black Economic Empowerment (BEE) is defined in a Strategy Document by the Department of Trade and Industry (DTI) as being 'an integrated and coherent socio-economic process that contributes to the economic transformation of South Africa to bring about significant increases in the numbers of black people that manage, own and control the country's economy, and significant decreases in income inequalities' ${ }^{69}$

In the mid-1990s, the concept of broader economic inclusion and transformation was driven by South African corporations, with no clear frameworks or targets in place. The BEE Commission was launched by the government in 1998, at which time only three per cent of the shares of JSElisted companies were owned by those targeted to be empowered under to the BEE legislation. This percentage was about 17 per cent by 2014. In the early 2000s, a number of BEE definitions and ownership targets were put forward, with charters such as the Mining Industry Charter being developed, together with the release of the Department of Trade and Industry's Broad-Based Black Economic Empowerment (B-BBEE) Strategy Document on BEE in 2003.

Following the promulgation of the B-BBEE Act in 2004, the BEE Codes of Good Practice (2007 and 2013) ${ }^{70}$ were formulated, and BEE Codes adopted, providing a standard framework for scoring specific industries, taking into account elements including ownership, control, employment equity, skills development, preferential procurement and enterprise development. Industryspecific charters and scorecards have been developed under the terms of the Act in order to apply the broader B-BBEE framework. These charters have been drafted through a participatory approach, with major stakeholders in various sectors of the economy being consulted. Sector charters thus promote the

\footnotetext{
${ }^{68}$ Broad-Based Black Economic Empowerment Act 2003 (South Africa).

${ }^{69}$ Department of Trade and Industry Republic of South Africa, South Africa's Economic Transformation: A Strategy for Broad-Based Black Economic Empowerment, 6 $<$ https://www.thedti.gov.za/economic_empowerment/docs/bee_archive_docs/CodeofGoodPra ctice.pdf $>$.

70 Department of Trade and Industry, Broad-Based Black Economic Empowerment Act (53/2003): Issues of Good Practice in South Africa, Government Gazette Staatskoerant, No 36928, 11 October 2013, 3, 10 <http://www.dti.gov.za/news2013/code_gud_practice 10102013.pdf $>$.
} 
commitment of stakeholders to support 'transformation', that is, women's empowerment in each specific sector and industry.

Across these sectors, and in line with the above-listed elements, scorecards are used as a monitoring mechanism to measure an organisation's commitment to transformation in its respective sector and in line with the targets set. Noncompliance with legislation precludes the possibility of an organisation winning government contracts and tenders, but in most sectors does not result in any penalties. Where a sector charter does not apply to a specific industry or is still being developed, the B-BBEE Codes of Good Practice are applied in the development, evaluation and monitoring of BEE Charters, initiatives, transactions and other implementation mechanisms. ${ }^{71}$ Judging by information on each of the sector charters and codes collected through a questionnaire directed at players and stakeholders active in the respective industries, sector targets, timelines, progress, and commitment on transformation vary greatly.

\section{ADOPTION OF THE WOMEN EMPOWERMENT AND GENDER EQUALITY BILL (WEGE BILL)}

In March 2014, the Women Empowerment and Gender Equality Bill (WEGE Bill $)^{72}$ passed in the National Assembly and was referred to the National Council of Provinces, an entity constitutionally mandated to ensure that provincial interests are taken into account in the sphere of national government. The Bill is to strengthen existing empowering Acts, and to empower women. ${ }^{73}$ At ballot, it garnered 195 votes in favour, 38 against and three abstentions. The Bill calls for 50 per cent gender equality in all decision making structures and this stipulation has to be part of the gender mainstreaming strategies, plans and programs of the organisation. The Bill will significantly change the working space in South Africa as it provides a framework for creating an enabling working environment for women and men.

Other Bill stipulations include:

- Improving women's access to education, training and skills development;

\footnotetext{
${ }^{71}$ BEE Navigator, BEE Info <http://www.bee-scorecard.co.za/bee_information.html >.

72 See <http://www.parliament.gov.za/live/commonrepository/Processed/20131108/553400_ 1.pdf $>$.

${ }^{73}$ Ibid, s 3.
} 
- Promoting public education programs that deal with gender discrimination and violence, and promote social cohesion;

- Increasing women's access to finance;

- Ensuring that childbearing responsibilities are not a reason to leave educational institutions;

- Training women on their reproductive rights under the Constitution;

- Increasing the availability of access to healthcare specific to women's needs.

Companies will have to complete a gender equality analysis with a view to reducing disparities between men and women and will have two years from the adoption of the Act to become compliant. Non-compliance could result in a fine of up to 10 per cent of the company's annual turnover, and criminal charges for officers of public entities in charge of the gender equality analyses. The Bill requires both designated public bodies and designated private bodies to submit their plans on how they are to achieve the progressive realisation of 50 per cent representation of women within the area of work and according to available resources.

\section{A What Is the Guarantee That the Bill Will Be Effectively Monitored?}

Existing bodies such as the Department of Labour's Commission on Employment Equity would be utilised to monitor the Bill. The Minister would work with the Department of Labour and other Departments, such as the Department of Performance Monitoring and Evaluation in the Presidency,${ }^{74}$ to carry out the monitoring.

\section{B Latest Update on WEGE Bill}

As at 13 July 2014 the Department of Women has allayed concerns about reports of talks in the Portfolio Committee on Women in the Presidency concerning the possible withdrawal of the Women Empowerment and Gender Equality (WEGE) Bill. This follows a portfolio committee briefing on the ministry's Annual Performance Plan 2014/15 and its budget. The briefing, held on 1 July 2014, was led by Minister in the Presidency Responsible for Women,

\footnotetext{
${ }^{74}$ See $<$ http://www.thepresidency-dpme.gov.za/Pages/default.aspx $>$.
} 
Susan Shabangu. Minister Shabangu informed the committee that the WEGE Bill will have to be reviewed, as the National Council of Provinces adopted the Bill with amendments. ${ }^{75}$ The review process would allow the Department of Women to further consult with stakeholders.

\section{CURRENT QuOTA Statistics Globally AND IN SOUTH AFRICA}

\section{A Global Quota Statistics}

No country in the world has yet achieved equality between men and women. According to the World Economic Forum's Global Gender Gap Report 2013 - based on the eight years of data available for the 110 countries that have been part of the Report since its inception - the majority of countries have made slow progress on closing gender gaps, with the most progress being made in Scandinavian countries. ${ }^{76}$ Iceland continues to be at the top of the overall rankings for the fifth consecutive year. Finland ranks in second position (previously $3^{\text {rd }}$ ), and Norway holds third place (previously $2^{\text {nd }}$ ) in the overall ranking. Sweden remains in fourth position. Northern European countries dominate the top ten, with Ireland in the sixth position, Denmark eighth and Switzerland ninth. New Zealand (7), the Philippines (5) and Nicaragua (10) complete the top 10 .

The World Economic Forum’s Global Gender Gap Report 2013 continues to track the strong correlation between a country's gender gap and its national competitiveness. ${ }^{77}$ Because women account for one half of a country's potential talent base, a nation's competitiveness in the long term depends significantly on whether and how it educates and empowers its women.

\section{B South Africa Statistics}

In terms of closing the gender gap, South Africa is one of the top 20 countries as measured by the World Economic Forum’s Global Gender Gap Report. The

\footnotetext{
${ }^{75}$ Southern Africa Trust, Interview with Kenosi Machepae, Department of Women spokesperson, 'Making gender equality a practical reality' (Mail \& Guardian, 26 June 2014) $<$ http://mg.co.za/article/2014-06-26-making-gender-equality-a-practical-reality> .

${ }^{76}$ World Economic Forum, above n 55, 7 ff (Tables 3a-3c). The World Economic Forum's Global Gender Gap Report 2013 benchmarks national gender gaps of 136 countries on economic, political, education- and health-based criteria.

${ }^{77}$ Ibid.
} 
country was ranked $12^{\text {th }}$ in the world by the report in 2010 , and $6^{\text {th }}$ in 2009 . This demonstrates increasing equality between men and women in South Africa.

While the country's ranking has dropped since 2009, it remains the only African country, along with Lesotho, in the top 20. It also ranked higher than some of the world's most developed countries, such as the United States (19), Germany (13) and the United Kingdom (15).

South Africa scores particularly well in the political empowerment of women, ranking $9^{\text {th }}$ overall. However, the country ranks $43^{\text {rd }}$ in female educational attainment, $101^{\text {st }}$ in women's health and survival, and $55^{\text {th }}$ in women's economic participation and opportunity, indicating that significant gaps still exist, especially in the education, health and economic participation of women in comparison to men.

Combined, the figures give South Africa (ranking $17^{\text {th }}$ in the world) a point score of 75.3 per cent, which is the percentage of the gender gap that has been closed. This score is similar to the scores for Switzerland, Spain, Germany and Belgium.

\section{$1 \quad$ Government Statistics}

South Africa's 'new cabinet comprises 15 female Ministers out of a total cabinet of 37 (including the President and his Deputy). This means that women ministers constitute about $40 \%$ of the membership of the new cabinet while male members of the cabinet constitute $60 \%$. $^{78}$

\section{$2 \quad$ Corporate and Private Entity Statistics}

In the private sector before 2011, women seldom held more than 12 per cent of senior and top management positions. ${ }^{79}$ In 2014 women comprised 47 per cent of the skilled workforce, 43 per cent of those with professional qualifications, 30 per cent of senior managers, and 21 per cent of top executive management. ${ }^{80}$ Women were better represented among CFOs than in any other senior

\footnotetext{
${ }^{78}$ Javu Baloyi, Women Constitute 40\% of New Cabinet - CGE (26 May 2014) Politics Web $<$ http://www.politicsweb.co.za/politicsweb/view/politicsweb/en/page71619?oid=624257\&sn= Detail\&pid=71619>. This is a significant step in the right direction.

79 Commission for Gender Equality (CGE), Annual Report 2011-2012 (2011) $<$ http://db3sqepoi5n3s.cloudfront.net/files/docs/121024cgeannual.pdf >.

${ }^{80}$ Commission for Employment Equity (CEE) Annual report 2103-2014: Sections 3 and 4: $<$ http://www.labour.gov.za/DOL/downloads/documents/annual-reports/employmentequity/2013-2014/14ceeannualreport.pdf $>$.
} 
management position in SA, at 32 per cent. ${ }^{81}$ A Price Waterhouse Coopers report states that 'South Africa's mining sector has the best level of female representation on boards'. In January 2015 there were '21.05\% women sitting on the boards of South Africa's top 100 listed mining companies'.$^{82}$

In 2011 only 4.4 per cent of the CEOs of JSE-listed companies, and only 5.3 per cent of the people who chair such companies, were women. ${ }^{83}$ Although 2015 figures are not available, it is clear that in October 2014 '[w]hite males still dominated JSE companies'. ${ }^{84}$

\section{$X$ WORKING TOWARDS A 50 PER CENT QUOTA IN SOUTH AFRICA}

\section{A Why Should We Be Concerned about Gender Equality in South Africa?}

Taking gender issues seriously makes good business sense since women make up over 50 per cent of the South African population, constituting a sizeable percentage of customers making decisions on what is to be bought and where. Women's economic power as consumers is growing by the day and businesses must strive to keep them happy and meet their needs. ${ }^{85}$

\section{B Is the $\mathbf{5 0}$ per cent Quota Target Realistic?}

A UK Report of 2011 drew attention to the fact that at the rate of change at that stage, it would have taken over 70 years to achieve gender-balanced

81 Grant Thornton, Women in Leadership Poll (16 July 2013) <http://www.gt.co.za/news/ corporate/2013/07/women-in-leadership/>.

${ }^{82}$ Price Waterhouse Coopers, South Africa's Mining Industry Ranks Top for Gender Diversity in the Boardroom, according to PwC Report <http://www.pwc.co.za/en/press-room/womenskills-mine.jhtml>. The Report was prepared by PwC in the UK in conjunction with sponsors Anglo American, Rio Tinto and Latham \& Watkins. See <http://www.pwc.com/gx/en/ceosurvey/2015/assets/pwc-18th-annual-global-ceo-survey-jan-2015.pdf $>$ for the full Report.

83 Southern Africa Gender Protocol Alliance, South Africa: Businesswomen's Association of South Africa Set to Release Women in Leadership Census, Genderlinks $<$ http://www.genderlinks.org.za/article/south-africa-businesswomens-association-of-southafrica-set-to-release-women-in-leadership-census-2012-06-04>.

84 Sapa Reporter, 'White males dominate JSE companies', TechCentral, 15 October 2014 $<$ http://www.techcentral.co.za/white-males-dominate-jse-companies/51745/>.

${ }^{85}$ Commission for Gender Equality, Best Practice Guidelines for Creating a Culture of Gender Equality in the Private Sector Genderlink <http://www.workinfo.com/free/downloads/ genderlink.htm>. 
boardrooms in the UK. ${ }^{86}$ In South Africa, with a current female representation of 21 per cent on boards, it would depend on 'the pipeline of candidates entering the workforce in a particular discipline'. South Africa needs to 'align quotas with the availability of suitably qualified women'. ${ }^{87}$

Women should be mentored and skilled from within the company, using its available resources and capacities to empower them. Currently what is found is that companies say they are looking for women to fill positions in their companies, but that intent is not followed by action.

\section{What Steps Will Be Required to Train and Recruit Women?}

There is no shortage of skills in South Africa. The country just has not tapped into the potential of women; once it does, it will easily fill all its skills gaps. The first step is to focus on gender equality in education, since this builds the foundation for increasing the number of skilled, professional women entering the workplace. The objective is 'to empower and increase the number of women in gainful employment'. ${ }^{88}$

\section{Practical Reality Associated with Certain Professions and Jobs}

New research suggests that, of all the technical fields, engineering is one of the worst offenders for gender equity worldwide..$^{89}$ Close to 40 per cent of women who earn degrees in the field leave their jobs prematurely, or never apply for jobs in the area in the first place. Of those who left their engineering jobs, most say that they were pushed out by poor workplace environments or mistreatment by managers and co-workers. ${ }^{90}$

\footnotetext{
${ }^{86}$ Lord Davies, Women on Boards (February 2011) Government of the United Kingdom, 3 $<$ https://www.gov.uk/government/uploads/system/uploads/attachment_data/file/31480/11-

745-women-on-boards.pdf $>$.

87 Is Gender Equality Stalling? (22 May 2014) iafrica.com <http://business.iafrica.com/ news/939869.html> citing Sandra Burmeister, CEO of Amrop Landelahni.

${ }^{88}$ Ibid.

${ }^{89}$ Nadya Fouad, Leaning in, but Getting Pushed Back (and Out) (7-10 August 2014) American Psychological Association <http://www.apa.org/news/press/releases/2014/08/pushed-back. pdf $>$.

${ }^{90}$ Ibid. The findings of the research presented at the 2014 Annual Convention of the American Psychological Association have been referred to widely. See, for example, Erin Brodwin, ‘There’s an Alarming Trend among Female Scientists Who "Lean In” at Work', Identities.Mic
} 
Globally there are significantly fewer women than men working in technical and engineering disciplines. ${ }^{91}$ In 2014 Sandra Burmeister, CEO of Amrop Landelahni, commented on the reality in South Africa of trying to achieve 50 per cent women in certain jobs:

In South Africa, a blanket target of 50\% women will pose difficulties for sectors where two-thirds of workers are technical - such as in construction, infrastructure and information technology. A fixed 50\% target is not realistic since there simply may not be enough women to fill half the positions in all types of jobs. ${ }^{92}$

\section{E Will All These Scorecards, Quotas and Codes Force Companies to Change?}

In many companies there is an even split of men and women at entry-level employment, but women are lost between the middle and senior levels. There are many reasons for this, and companies know now more than ever that they need to have systems in place to develop women's progress to the top to get these quotas in place. They think, however, that they can change in their own time.

\section{F Do We Still Need the Bill after All South Africa's Gender Equality Legislation?}

At the national level, various pieces of legislation and policies have been crafted and implemented that address the issues of women's economic empowerment, gender inequality and equity in South Africa. ${ }^{93}$ There is thus no shortage of appropriate policies aimed at creating enabling environments. There is also an abundance of international instruments and frameworks that South Africa endorses and that provide initiatives and suggestions for women to advance to top positions. However, 'businesses [needed to force] the government's hand

\footnotetext{
(11 August 2014) <http://mic.com/articles/95912/there-s-an-alarming-trend-among-femalescientists-who-lean-in-at-work>.

${ }^{91}$ Brodwin, above $\mathrm{n} 90$.

92 'Is Gender Equality Stalling?’ iafrica.com (22 May 2014) <http://business.iafrica.com/news/ 939869.html>.

${ }^{93}$ International Women's Forum South Africa, above n 29, 44.
} 
[to implement the WEGE Bill] as it had not taken gender transformation seriously'. ${ }^{94}$

South Africa therefore needs this Bill as reinforcement and a reminder to work towards gender diversity.

\section{WOMEN'S QUOTA IMPACT ON Companies' REPUTATION}

\section{A The Reputational Transformation Imperative}

Research data supports the link between gender diversity and corporate performance..$^{95}$ It is not that women cause a company to make more money per se, but that including females in leadership shows a pattern of best practice that gives companies a reputational competitive advantage. If employers thought more about the needs of female workers it would enhance productivity and result in higher employee retention.

\section{B Gender-Diverse Boards Positively Affect CSR Ratings}

Bear, Rahman and Post have found that having female directors on boards enhances a company's Corporate Social Responsibility (CSR) ratings, which in turn increases its corporate reputation. ${ }^{96}$ They suggest that gender diversity is a very visible indicator of an organisation's commitment to diversity, and diversity is linked to perceptions about an organisation's commitment to ethical values such as good corporate citizenship. ${ }^{97}$ It may also be that women and men together draw upon a broader range of life experiences when making decisions about CSR initiatives. ${ }^{98}$

\footnotetext{
${ }^{94}$ Ntsakisi Maswanganyi, Business Warns of Red Tape Burden of Gender Bill (11 November 2013) Business Day Live <http://www.bdlive.co.za/business/2013/11/11/business-warns-ofred-tape-burden-of-gender-bill $>$.

${ }^{95}$ Credit Suisse Research Institute, above n 38.

${ }^{96}$ Stephen Bear, Noushi Rahman and Corinne Post, 'The Impact of Board Diversity and Gender Composition on Corporate Social Responsibility and Firm Reputation' (2010) 97 Journal of Business Ethics 207, 221.

${ }^{97}$ Ibid.

${ }^{98}$ Ibid.
} 


\section{Gender-Diverse Boards Draw Investors}

There is a greater demand for values-based investments that use a gender lens. ${ }^{99}$ Clients have started asking about diversity on corporate boards, particularly with respect to women since diversity brings disruption and can lead to better ideas. ${ }^{100}$ Fortune 500 companies with three or more female board members significantly outperformed those with no female board members in at least four of five years. ${ }^{101}$

\section{ACtions AND SOlutions: HoW to ReACH THE 50 PER CENT QUOTA In SOUTH AFRICA}

The private sector in South Africa has an important contribution to make to the achievement of gender equality. The increased participation of women in the labour market and economy in general is likely to help in developing a strong and broad skills base for the economy. 'The challenge is to ensure this leads to women's economic empowerment and does not further exacerbate inequalities between women and men.' 102

The following is a list of actions that could be taken to reach the 50 per cent quota in South Africa.

\section{- Having a Policy in Place for Gender Mainstreaming}

The objective of a Gender Policy is to serve as a tool and framework for establishing performance requirements which enhance gender equality, and to encourage business to integrate gender into key organisational practices, considering that women and men have different needs.

In working towards transformation of gender relations, the rights and responsibilities of women and men at all levels need to be redefined. The

\footnotetext{
99 Jackie VanderBrug, senior vice president at US Trusts portfolio analytics, consulting and institutional group, quoted in Corrie Driebusch, 'Gender-Diverse Boards Draw Investors', The Wall Street Journal (9 February 2014) <http://online.wsj.com/articles/SB10001424 052702304549504579318283326502974> (article available on request).

${ }^{100}$ Statement by Jason Katz, a New York-based financial adviser with UBS Wealth Management Americas, referred to in Driebusch, ibid.

101 Catalyst, Why Diversity Matters (2013), 5 <http://www.catalyst.org/system/files/why_ diversity_matters_catalyst_0.pdf $>$.

102 Commission for Gender Equality, Best Practice Guidelines for Creating a Culture of Gender Equality in the Private Sector Genderlinks <http://www.workinfo.com/free/downloads/ genderlink.htm>.
} 
formulation of a gender policy is an indication of an organisation's commitment to this transformation process. A gender policy also promotes a generic understanding of the principles within the entire organisation, and facilitates the continuous monitoring of the policy. ${ }^{103}$

\section{- Ensuring Proper Remuneration of Women}

Policies must address pay parities, ensuring equal pay for work of equal value. Women are income earners in their own right. To pay women lower wages on the basis that women do not really need more because their husbands will earn better wages, is not only discriminatory; it is unlawful. 'Jobs must be graded in terms of their content and value, not in terms of which sex does them', and 'performance management and appraisal must be equitable'. ${ }^{104}$

\section{- Offering Women Improved Education and Training}

Secondary and higher levels of education are an important vehicle for transforming attitudes, beliefs, and entrenched social norms that perpetuate discrimination and inequality. Education can lead to more employment opportunities, increased income prospects and more resources at the household level. It is necessary to deliberately train women for jobs that have traditionally been the preserve of men, and to increase expenditure on basic literacy training. ${ }^{105}$

\section{- Improving Infrastructure}

There are several studies on African countries showing that women in particular suffer from a lack of infrastructure such as electricity, transport and water. Thus, they must walk long distances to fetch firewood and water. ${ }^{106}$ Improving

\footnotetext{
${ }^{103}$ Commission for Gender Equality, Best Practice Guidelines for Creating a Culture of Gender Equality in the Private Sector Genderlinks <http://www.workinfo.com/free/downloads /genderlink.htm>.

${ }^{104}$ Ibid.

${ }^{105}$ UN Millennium Project Task Force on Education and Gender Equality, Taking Action: Achieving Gender Equality and Empowering Women (2005) United Nations Development Programme <http://www.unmillenniumproject.org/documents/Gender-complete.pdf> .

${ }^{106}$ See, for instance, International Centre for Research on Women, Infrastructure Shortfalls Cost Poor Women Time and Opportunity (2005) ICRW $1<$ <ttp://www.icrw.org/files/ publications/Infrastructure-Shortfalls-Cost-Poor-Women-Time-and-Opportunity-TowardAchieving-the-Third-Millennium-Development-Goal-to-Promote-Gender-Equality-andEmpower-Women.pdf $>$ and World Health Organisation, Gender, Climate Change and Health, WHO $14<$ http://www.who.int/globalchange/GenderClimateChangeHealthfinal.pdf>.
} 
infrastructure will improve not only their quality of life, but also enable them to make an even bigger contribution to society.

\section{- Ensuring that Government Provides Enabling Tools}

The government needs to develop tools to empower women and give them more opportunities despite the restrictions of a traditionally patriarchal society. Leaders and citizens need to commit to a bold, long-term programme that goes beyond short-term personal or political gain to encourage women to take on corporate responsibilities. ${ }^{107}$

\section{- Tightening B-BBEE Procurement Processes}

South Africa needs to critically examine the achievements of broad-based black economic empowerment and the extent to which businesses led by women benefit from stronger enforcement mechanisms for reporting under BEE legislation. ${ }^{108}$

\section{- Building Partnerships between Business and Financing Institutions}

It was stated in the International Women's Forum South Africa Report in 2011 that the 'way forward' involved:

Building and fostering partnerships between financing institutions, women organisations, government departments and businesses in order to better link the policy environment and the on the ground experiences of women. ${ }^{109}$

The National Empowerment Fund should also be providing working capital, and participating in transactions to 'finance the risk portions of finance structures'. ${ }^{110}$ In addition, consultative workshops should be held 'in order to share knowledge and information on the financing avenues and opportunities available to women entrepreneurs'. ${ }^{111}$

\footnotetext{
${ }^{107}$ UN Millennium Project Task Force on Education and Gender Equality, above n 105.

${ }^{108}$ Commission for Gender Equality, above n 103.

${ }^{109}$ International Women's Forum South Africa, above n 29, 47.

${ }^{110}$ Ibid 44.

${ }^{111}$ Ibid 47.
} 


\section{- Developing a Database of Key Women}

A 'database of key women and their skills' needs to be developed, 'drawing on already existing networks, in order to better match human capital requirements to human capital development initiatives'. ${ }^{112}$

Business women should use their position to influence those in power to employ women to fill upcoming high level vacancies. Business women should also support women in politics so that the issue of women's empowerment is at the forefront of political agendas.

\section{- Providing Role Models to Younger Women}

'Successful and leading business women [should] take it upon themselves to be role models that can inspire younger women' and 'take on responsibilities of providing opportunities to younger and less experienced women through ... female procurement policies'. ${ }^{113}$

\section{- Closing the Gap between Men and Women}

Achieving quota goals will be impossible without closing the gaps between women and men in terms of access to resources and opportunities, and vulnerability to violence and conflict. Men and women should be able to work together and work out support systems that would enable both to advance diversity.

\section{- Encouraging Youth Entrepreneurship}

South Africa is a 'young country with over 51\% of the population being under 25 . ${ }^{114}$ There is thus a need for attention to be focused on the creation of opportunities for the youth. It is necessary to encourage 'a culture of development and acceleration among corporations' and to find ways to 'encourage young people to become pro-active and give them confidence in the ability to become future entrepreneurs'. ${ }^{115}$

\footnotetext{
112 Ibid 48.

113 Ibid 44.

${ }^{114}$ Ibid 47.

115 Ibid 46.
} 


\section{- Reaching Women at the Bottom of Society}

Discussions surrounding gender equity 'should recognize widening disparities and "the key focus has to be on those women at the bottom" of society'. ${ }^{116} \mathrm{~A}$ 'coherent strategy' needs to be built 'by establishing separate commissions for state-owned entities, municipalities and rural development, to ensure that the challenges in these areas such as a lack of skills and capacities are addressed sufficiently'. ${ }^{117}$

\section{- Not Isolating Women's Empowerment from Government}

'Dealing with gender issues at government and departmental levels should not be an isolated issue'. ${ }^{118}$ The ministry 'should address this problem by establishing links with policy plans such as the Industrial Policy Action Plan 2 (IPAP2)'. ${ }^{119}$

\section{- Growing Women into the Position}

The makeup of corporate boards of directors should be representative of the stakeholders of the company which they govern: shareholders, employees, and customers. To ensure there is no significant gender imbalance at board level, it is critical that businesses support, mentor, train and nurture talent from the grassroots all the way to the top. Developing this pipeline will help to ensure that talent pools are sufficiently diverse that the best person is chosen as a board member. ${ }^{120}$

\section{CONCLUSION}

What has been evident is that South Africa has made progress in terms of women's empowerment and the reduction of discrimination towards women in the workplace. However, this has only been the beginning of a far longer

\footnotetext{
116 Ibid.

117 Ibid 44.

118 Ibid 44-5.

${ }^{119}$ Ibid 45. See the Department of Trade and Industry Republic of South Africa, Industrial Policy Action Plan 2013/14-2015/16 (2013) <http://www.thedti.gov.za/news2013/ipap_20132016.pdf>.

${ }^{120}$ Lord Davies, above n 86, 15-16, 34.
} 
journey, particularly with regard to the progress that is still to be made in the private sector.

Only time will tell whether it will be possible to reach a 50 per cent quota by 2017, as many factors make the process complex and intricate. However, as a country committed to good corporate governance, South Africa will continue to pursue this.

To conclude this paper with Nelson Mandela's words,

Women and girls need safe environments to learn and to work. At the moment, discrimination and violence exacerbate their lack of access to the very tools they need to make their own rights a reality. If girls do not have a safe and non-discriminatory environment to pursue education or gain employment, the consequences reverberate throughout their lives, denying them the choice and freedom we take for granted. ${ }^{121}$

121 Nelson Mandela, While Poverty Persists, There Is No Freedom (2006) The Guardian $<$ http://www.theguardian.com/commentisfree/2006/nov/04/development.internationalaidandd evelopment>. This speech was given in Johannesburg in November 2006 when Mandela became an Amnesty International ambassador of conscience. 